\title{
BENTUK PELANGGARAN HUKUM NOTARIS DI WILAYAH PROVINSI BANTEN DAN PENEGAKAN HUKUMNYA*
}

\author{
Endang Purwaningsih ${ }^{* *}$
}

\author{
Bagian Hukum Bisnis, Fakultas Hukum Universitas YARSI, Jakarta \\ Jalan Let. Jend. Suprapto, Cempaka Putih, Jakarta Pusat 10510
}

Abstract

Notaries might make mistakes in doing duties which result in legal problems. The types of legal breaches by notaries in Banten: (1) not reading authentic certificates, (2) not witnessing the documents signed before them, (3) not practicing in destined area, (4) opening more than one office, (5) having a 'notary'signpost but with an inactive, (6) moving to a new address without reporting, and (7) producing a copy which's different from the minutes. Law enforcement to prevent: (1) illumination, (2) coordination and relationship, (3) continuous observation, (4) better selection, (5) preventive observation, and (6) independent institution.

Keywords: types of breaches, notary, preventive measure.

\section{Intisari}

Notaris dimungkinkan melakukan kesalahan dalam melaksanakan tugas jabatannya. Bentuk-bentuk pelanggaran hukum yang dilakukan Notaris di Banten: (1) tidak membacakan akta, (2) tidak tanda tangan di hadapan Notaris, (3) tidak berada di wilayah kerja yang ditentukan, (4) membuka kantor lebih dari satu, (5) plang nama Notaris terpampang tetapi kosong, (6) pindah alamat kantor tetapi tidak melapor, (7) membuat salinan akta tidak sesuai dengan minuta. Pencegahan dalam rangka penegakan hukum: (1) pembinaan (2) koordinasi dan kerjasama, (3) pengawasan yang kontinu, (4) seleksi yang lebih baik; (5) pengawasan dengan tujuan preventif, dan (6) lembaga independen.

Kata kunci: bentuk pelanggaran, Notaris, upaya pencegahan.

\section{Pokok Muatan}

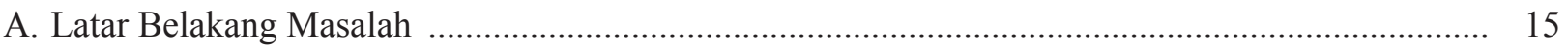

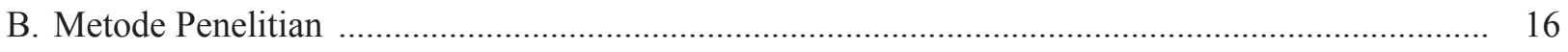

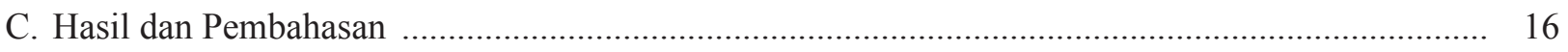

1. Bentuk-Bentuk Pelanggaran Hukum oleh Notaris di Wilayah Provinsi Banten ....................... 16

2. Penegakan Hukum Preventif terhadap Pelanggaran Hukum oleh Notaris di Wilayah Provinsi

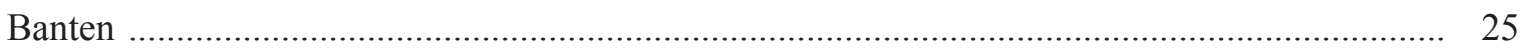

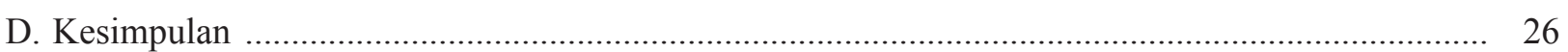

Hasil Penelitian Fakultas Hukum Universitas YARSI, Tahun 2014.

Alamat korespondensi: e.purwaningsih@yarsi.ac.id 


\section{A. Latar Belakang Masalah}

Notaris adalah pejabat umum yang berwenang untuk membuat akta otentik dan kewenangan lainnya sebagaimana dimaksud dalam Undang-Undang Nomor 30 Tahun 2004 tentang Jabatan Notaris (selanjutnya disingkat UUJN). Dalam rangka melaksanakan amanah pasal tersebut, Notaris mengemban tugas penting untuk melayani kepentingan masyarakat. Pasal 4 UUJN menegaskan bahwa sebelum menjalankan jabatannya, Notaris wajib mengucapkan sumpah/ janji menurut agamanya bahwa akan patuh dan setia kepada Negara Republik Indonesia, Pancasila dan Undang-Undang Dasar Negara Republik Indonesia Tahun 1945, Undang-Undang tentang Jabatan Notaris serta peraturan perundang-undangan lainnya serta akan menjalankan jabatan dengan amanah, jujur, saksama, mandiri, tidak berpihak dan akan menjaga sikap, tingkah laku, akan menjalankan kewajiban sesuai dengan kode etik profesi, kehormatan, martabat, dan tanggung jawab sebagai Notaris, juga akan merahasiakan isi akta dan keterangan yang diperoleh dalam pelaksanaan jabatan Notaris.

Dalam melaksanakan tugasnya melayani kepentingan masyarakat, Notaris seharusnya menjaga harkat martabatnya. Tan Thong $\mathrm{Kie}^{1}$ menyatakan bahwa terdapat kebiasaan di kalangan Notaris yang tidak lagi membaca aktanya sehingga akta itu menjadi akta di bawah tangan. Di dalam akta ia menulis bahwa akta itu "telah dibacakan oleh saya, Notaris, padahal ia tidak membacanya. Ia berbohong dan dengan itu membuat pemalsuan akta. Apalagi banyak Notaris membiarkan para penghadap menandatangani akta di hadapan asistennya, sehingga keterangan Notaris itu "telah berhadapan dengan para penghadap" perlu diragukan pula. Bahwa dengan tidak membaca akta dan tidak melihat siapa yang menandatangani akta, Notaris yang berbuat demikian menurunkan martabat pekerjaan dan jabatannya yang mulia itu.

Dalam upaya menjaga Notaris agar menegakkan tugas jabatan mulia tersebut, maka dilakukan pengawasan. Menurut anggota Majelis Pengawas Pusat Widodo Suryandono, ${ }^{2}$ di wilayah DKI Jakarta dalam kurun waktu sekurangkurangnya setahun belakangan, pelanggaran yang dilaporkan kepada MPP adalah pelanggaran hukum di luar jabatan Notaris, misalnya penipuan atau penggelapan.

Winanto Wiryomartani ${ }^{3}$ anggota Majelis Pengawas Pusat menyatakan bahwa pengawasan Notaris pada dasarnya adalah untuk melindungi masyakat. Menurut Winanto Wiryomartani, Notaris adalah pejabat umum untuk melayani masyarakat, jadi dalam rangka pembuatan akta otentik oleh Notaris, masyarakat wajib dilindungi. Untuk itulah makanya dibentuk Majelis Pengawas yang fungsinya melindungi masyarakat jika terjadi pelanggaran hukum oleh Notaris. Pengawasan ini tujuannya adalah pencegahan terhadap terjadinya pelanggaran yang merugikan masyarakat.

Syafran Sofyan ${ }^{4}$ menyatakan bahwa Notaris sebagai pejabat umum yang memiliki kualitas intelektual memadai dan bukan sekedar "tukang" atau "juru tulis" semata-mata. Dalam hal terjadi kesalahan, hal ini bisa merupakan malapraktik (negligence) dengan parameter akibat kurang pengetahuan atau kurang pengalaman dengan konsekuensi sanksi administrasi, perdata atau etik, namun bisa membawa konsekuensi pidana menurut KUHP apabila memenuhi syarat-syarat pemidanaan tersebut di atas atas dasar kecurangan yang sengaja dilakukan Notaris.

Sebagai pejabat umum yang bertugas melayani kepentingan umum, yakni membuat aktaakta, dimungkinkan terjadi masalah hukum yang bersumber dari pelaksanaan tugas dan wewenang Notaris tersebut. Satu kalimat dalam suatu akta otentik mungkin saja menimbulkan kasus pidana

\footnotetext{
Tan Thong Kie, 2007, Studi Notariat Serba Serbi Praktek Notaris, Ikhtiar Baru, Jakarta, hlm. 634.

Widodo Suryandono, "Sudah Pindah Tapi Masih Pasang Papan Nama", www.medianotaris.com, diakses 1 Oktober 2012

Winanto Wiryomartani, "Sudah Pindah Tapi Masih Pasang Papan Nama”, www.medianotaris.com, diakses 1 Oktober 2012
}

Syafran Sofyan, "Notaris Bukan Tukang Jangan Takut Dipanggil Penyidik”, www.medianotaris.com, diakses 1 Oktober 2012. 
atau perdata, dan masalah ini timbul karena kurang hati-hati, tidak teliti ketika Notaris membuat akta, bahkan dengan iktikad baik, sengaja atau pun tidak sengaja. Untuk itu perlu dikaji secara mendalam, penegakan UUJN dan Kode Etik Notaris dalam pelaksanaan tugas dan wewenang Notaris sebagai pejabat umum, khususnya dalam rangka mencegah terjadinya tindak pelanggaran. Dengan latar belakang tersebut, permasalahan penelitian ini dirumuskan sebagai berikut. Pertama, bagaimana bentuk-bentuk pelanggaran hukum yang terjadi dalam pelaksanaan jabatan Notaris dan Profesi Notaris di wilayah Banten?; dan Kedua, bagaimana penegakan hukum dalam upaya mencegah tindak pelanggaran hukum yang dilakukan oleh Notaris?

\section{B. Metode Penelitian}

Penelitian ini termasuk dalam penelitian normatif dengan didukung data empiris, atau dalam penelitian hukum biasa disebut normatif terapan/normatif empiris. Pendekatan yang digunakan adalah pendekatan perundangan (statute approach); pendekatan kasus (case study) dan pendekatan sosiologis (sociologisch approach). Lokasi penelitian dikhususkan pada daerah Banten dengan alasan bahwa jumlah Notaris di antara daerah Jabodetabek terbanyak di daerah Provinsi Banten. Kajian dilakukan melalui literary study terhadap bahan hukum primer, bahan hukum sekunder dan bahan hukum tersier; serta didukung data empiris berupa pendapat narasumber dengan wawancara mendalam (indepth interview). Data diperoleh adalah (lebih utama) berupa data sekunder dari kepustakaan, dan data primer berasal dari pengamatan, dan wawancara. Teknik pengolahan dan analisis data yang digunakan oleh penulis dalam penelitian ini ialah teknik analisis kualitatif. ${ }^{5}$

\section{Hasil Penelitian dan Pembahasan \\ 1. Bentuk-Bentuk Pelanggaran Hukum oleh Notaris di Wilayah Provinsi Banten}

Berdasarkan data yang diperoleh selama penelitian baik contoh kasus yang diberikan MPW Provinsi Banten maupun hasil wawancara, diketahui sejumlah 31 pelanggaran selama tahun 2008 sampai 2013 terjadi di wilayah Provinsi Banten dengan rincian sebagai berikut.

Tabel 1.

\section{Bentuk dan Jumlah Pelanggaran Tahun 2008-2013}

\begin{tabular}{llc}
\hline No. & Bentuk Pelanggaran & Jumlah \\
\hline 1 & Tidak bacakan akta & 3 \\
2 & $\begin{array}{l}\text { Tidak tanda tangan di hadapan } \\
\text { Notaris }\end{array}$ & 3 \\
3 & $\begin{array}{l}\text { Berada di luar wilayah kerja yang } \\
\text { telah ditentukan }\end{array}$ & 5 \\
4 & $\begin{array}{l}\text { Membuka kantor lebih dari 1 } \\
\text { Plang nama Notaris terpampang }\end{array}$ & 5 \\
tapi kosong & 5 \\
\hline & $\begin{array}{l}\text { Pindah alamat kantor tapi tidak } \\
\text { melapor }\end{array}$ & 5 \\
\hline $\begin{array}{l}\text { Buat salinan akta tidak sesuai } \\
\text { dengan minuta }\end{array}$ & 5 \\
\hline & Jumlah & 31 \\
\hline
\end{tabular}

Sumber: Hasil Penelitian di Sekretariat MPW

Provinsi Banten Mei - Oktober 2013.

\section{a. Notaris Tidak Membacakan Akta}

Pada kasus Notaris RW diketahui Notaris tidak membacakan akta di hadapan para penghadap dengan dihadiri oleh paling sedikit 2 (dua) orang saksi dan ditandatangani pada saat itu juga oleh para penghadap. Mencermati permasalahan pada kasus RW ini, perlu diperhatikan syarat formil pembuatan akta antara lain:

(1) dibuat di hadapan pejabat yang berwenang yaitu di hadapan Notaris;

(2) dihadiri oleh para pihak;

(3) kedua belah pihak dikenal atau dikenalkan kepada notaris;

(4) dihadiri oleh dua orang saksi;

(5) menyebut identitas Notaris, penghadap dan para saksik;

(6) menyebut tempat, hari, tanggal, bulan, tahun dibuatnya akta;

(7) Notaris membacakan akta di hadapan 
penghadap dan saksi-saksi;

ditandatangani oleh semua pihak, saksi, dan Notaris;

(9) penegasan pembacaan, penerjemahan, dan penandatangan pada penutup akta; dan

(10) mengenai kedudukan Notaris di daerah kabupaten atau kota.

Apabila salah satu saja syarat tersebut tidak terpenuhi, maka akan mengakibatkan akta Notaris yang bersangkutan cacat formil, akibatnya akta tersebut kehilangan kekuatan pembuktian sempurnanya, dan hanya menjadi akta di bawah tangan.

Merujuk dan sependapat dengan Tan Thong $\mathrm{Kie}^{6}$ yang menyatakan bahwa terdapat kebiasaan di kalangan Notaris yang tidak lagi membaca aktanya sehingga akta itu menjadi akta di bawah tangan. Di dalam akta ia menulis bahwa akta itu "telah dibacakan oleh saya, Notaris", padahal ia tidak membacanya. Ia berbohong dan dengan itu membuat pemalsuan akta. Apalagi banyak Notaris membiarkan para penghadap menandatangani akta di hadapan asistennya, sehingga keterangan Notaris itu "telah berhadapan dengan para penghadap" perlu diragukan pula. Bahwa dengan tidak membaca akta dan tidak melihat siapa yang menandatangani akta, Notaris yang berbuat demikian menurunkan martabat pekerjaan dan jabatannya yang mulia itu. Seharusnya Notaris yang tidak membacakan akta diberikan sanksi yang bisa mengakibatkan efek jera, karena apabila hanya diberikan teguran lisan ataupun tertulis, kemungkinan akan mengulangi lagi.

\section{b. Para Pihak Tidak Tandatangan d Hadapan Notaris}

Berdasarkan hasil penelitian, diketahui bahwa dampak jumlah Notaris yang tiap tahun meningkat, sehingga di wilayah Provinsi Banten mencapai 1200 Notaris, bisa mengakibatkan persaingan yang tidak sehat. Notaris yang berperilaku baik dan melaksanakan tugas jabatannya secara profesional menjadi tersisih seiring bermunculannya Notaris baru yang sering melakukan pelanggaran. Kasus Notaris yang para pihaknya tidak bertanda tangan di hadapannya sekaligus Notaris tidak membacakan akta di hadapannya juga sering terjadi di wilayah Banten ini, hanya saja kemungkinan hanya sedikit yang diketahui/dilaporkan dan ditindaklanjuti. Praktek Notaris yang demikian sebenarnya tidak hanya melanggar sumpahnya tetapi bahkan bisa dikategorikan dengan Notaris tidak beriktikad baik dan sengaja ingin membuat akta palsu, yang mengarah pada perbuatan tindak pidana dan dapat diajukan ke pengadilan, namun dalam kenyataannya sulit dilakukan karena pada umumnya orang yang membutuhkan jasa Notaris tidak mengetahui dan bersikap tidak peduli atas praktek-praktek tersebut. Pada kasus RW Notaris Kabupaten Tangerang-Kota Tangsel, berdasarkan laporan Majelis Pengawas Wilayah Notaris Provinsi Banten kemudian membentuk Majelis Pemeriksa Wilayah Notaris Provinsi Banten Dengan Surat Keputusan Nomor W29/T.Pem/Not.01/2010 MPW Notaris Provinsi Banten tanggal 11 Januari 2010 perihal Pembentukan Majelis Pemeriksa Wilayah Notaris Provinsi Banten; dan dalam sidangnya pada tanggal 26 Januari 2010, Majelis Pemeriksa Wilayah Notaris Provinsi Banten dalam melakukan pemeriksaan terhadap Notaris tersebut dan berkas laporan dari kuasa hukumnya, ditemukan fakta-fakta bahwa Notaris tersebut telah membuat akta kuasa menjual di mana para pihak baik pemberi kuasa maupun penerima kuasa tidak menandatangani akta tersebut di hadapan Notaris. Mengacu pada Pasal 16 dan 17 UUJN, seharusnya Notaris bertindak jujur, saksama, mandiri, tidak berpihak dan menjaga kepentingan pihak yang terkait dalam pembuatan hukum. Oleh karena itu perbuatan Notaris tersebut telah mengakibatkan kerugian orang berupa peralihan Hak Atas Tanah dan Bangunan.

Mengikuti pendapat R. Subekti ${ }^{7}$ secara umum adanya tanda tangan dari para penghadap diperlukan 
dalam suatu akta Notaris. Hal ini menandakan para penghadap tersebut telah menyetujui apa yang terdapat atau yang diperjanjikan oleh kedua belah pihak, yaitu para penghadap itu sendiri. Membubuhi tanda tangan harus mempunyai arti sebagai melihat (membaca) dan menyetujui apa yang ditulis. Seharusnya menurut penulis, dalam melaksanakan tugas jabatan, Notaris harus mematuhi UUJN dan Kode Etik Notaris. Undang-Undang Nomor 30 Tahun 2004 tentang Jabatan Notaris yang merupakan pengganti Notaris Reglement Stb. 1860 nomor 3 Peraturan Jabatan Notaris (PJN) mengandung muatan hukum materiil dan hukum formil. Hukum materiil menyangkut ketentuan tentang kedudukan dan fungsi Notaris, seperti pada Pasal 1, demikian pula dengan pengawasan terhadap Notaris dan apa yang dibuatnya. Hukum formil tidak kurang pentingnya, misalnya sebagai alat pembuktian yang otentik harus dipenuhi semua ketentuan yang diperlukan agar suatu akta notaris mempunyai bentuk yang sah. Jika tidak dipenuhi ketentuan-ketentuan itu akan menyebabkan sifat otentiknya.

Berkaitan dengan akta yang dibuat Notaris, penandatanganan suatu akta harus dilakukan sesuai dengan tempat atau kedudukan dan wilayah kerja Notaris, sesuai dengan Pasal 18 ayat (1) dan (2) Undang-Undang Jabatan Notaris, yang berbunyi: Notaris mempunyai tempat kedudukan di daerah kabupaten atau kota, dan Notaris mempunyai wilayah jabatan meliputi seluruh wilayah provinsi dari tempat kedudukannya.

Guna melaksanakan tugas jabatannya, seorang Notaris secara formil seharusnya:

(1) melakukan pengenalan terhadap penghadap berdasarkan identitasnya diperlihatkan kepada Notaris.

(2) menanyakan dan mencermati kehendak para pihak,

(3) memeriksa bukti surat yang berkaitan dengan keinginan para pihak.

(4) memberikan saran dan membuatkan minuta untuk memenuhi keinginan para pihak tersebut.

(5) memenuhi segala teknik adiministratif pembuatan akta seperti pembacaan, penandatanganan, memberikan salinan, dan pemberkasan untuk Minuta;

(6) melakukan kewajiban lain yang berkaitan dengan pelaksanaan jabatan notaris; dan

(7) Memberikan pelayanan sesuai dengan ketentuan UUJN, kecuali ada alasan untuk menolaknya.

Notaris juga harus melihat identitas penghadap, apakah ia mewakili diri sendiri pribadi, atau mewakili badan atau institusi tertentu.

\section{c. Notaris Tidak Berada di Wilayah Kerja}

Pasal 18 ayat (1) UUJN menentukan bahwa Notaris harus berkedudukan di daerah kabupaten atau kota. Setiap Notaris sesuai dengan keinginannya mempunyai tempat dan kedudukan, dan berkantor di kabupaten atau kota sebagaimana dalam Pasal 19 ayat (1) UUJN. Pengertian pasal tersebut memberikan penjelasan bahwa Notaris dalam menjalankan tugasnya tidak hanya berada di tempat kedudukannya, karena Notaris mempunyai wilayah jabatan seluruh provinsi. Hal ini dijalankan dengan ketentuan bahwa Notaris ketika menjalankan tugas jabatannya yakni membuat akta di luar tempat kedudukannya, maka Notaris tersebut harus berada di tempat akta harus dibuat, dan pada akhir akta harus disebutkan tempat (kota atau kabupaten) pembuatan atau penyelesaian akta. Menjalankan tugas jabatan di luar tempat kedudukan Notaris dalam wilayah jabatan satu provinsi tidak merupakan suatu pelangaran.

Notaris membuat akta di luar wilayah jabatannya akan tetapi yang bersangkutan mencantumkan dalam akta tersebut seolah-olah dilakukan dalam wilayah hukum kewenangannya, atau seolah-olah dilakukan di tempat kedudukan dari Notaris tersebut melanggar Pasal 17 huruf (a) UUJN, Notaris dilarang untuk menjalankan jabatannya di luar daerah jabatannya. Akan tetapi dimungkinkan seorang Notaris membuat akta di luar wilayah jabatannya, antara lain:

(1) Pasal 942 jo. 397 KUH Perdata yaitu 
penyerahan surat rahasia untuk dibuka oleh harta peninggalan di dalam daerah tempat wasiat itu dibuka,

(2) Pasal 157, 159, 161 KUH Perdata, yaitu ada kemungkinan notaris menjalankan jabatannya di luar wilayahnya apabila Notaris tersebut baik dalam perkara perdata maupun dalam perkara pidana harus menyerahkan minuta aktanya dan membuat salinan dari akta itu untuk protokolnya.

\section{d. Notaris Membuka Kantor Lebih dari Ketentuan}

Jika seorang Notaris membuka kantor cabang dengan cara, setiap cabang dalam waktu yang bersamaan, melangsungkan dan memproduksi akta Notaris yang seolah-olah ke semua akta tersebut dibuat di hadapan Notaris melanggar pasal 19 UUJN. Makin ketatnya persaingan antar Notaris di suatu wilayah yang sama memungkinkan oknum Notaris berbuat melanggar UUJN ini. Persaingan sesama Notaris disebabkan karena makin banyaknya jumlah Notaris dalam suatu wilayah bisa saja makin ketat dan menjurus pada persaingan yang tidak sehat. Hal ini bisa ditandai dari upaya 'jemput bola' sehingga klien didatangi langsung oleh pegawai Notaris, dengan menawarkan tarif yang mungkin di bawah standar dan promosi via media elektronik/cetak. Sependapat dengan Arie Siswanto ${ }^{8}$ menegaskan bahwa untuk dapat dikualifikasi sebagai tindak persaingan, harus memenuhi 3 (tiga)unsur yakni: perjuangan, diperebutkan 2 (dua) orang atau lebih, dan terhadap obyek yang sama, maka penulis menyimpulkan bahwa saat ini memang sudah pada taraf persaingan antar rekan Notaris.

Seharusnya perilaku tersebut tidak perlu terjadi jika Notaris saling menjaga diri, harkat dan martabatnya dijunjung tinggi. Penulis juga sependapat dengan Liliana Tedjasaputra ${ }^{9}$ bahwa sekalipun keahlian seorang Notaris bisa dimanfaatkan sebagai upaya mendapatkan klien, namun dalam menjalankan tugas profesinya Notaris tidak semata-mata didorong oleh keinginan atau pertimbangan uang. Seorang Notaris profesional harus tetap berpegang teguh pada rasa keadilan yang hakiki, tidak terpengaruh oleh jumlah uang, dan tidak semata-mata membuat alat bukti formal untuk mengejar adanya kepastian hukum dengan mengabaikan rasa keadilan.

Dalam kode etik Notaris disebutkan bahwa Notaris dalam menjalankan jabatannya dilarang mempunyai lebih dari 1 (satu) kantor baik kantor cabang atau perwakilan. Bahkan memasang papan nama di luar lingkungan kantor sebagai upaya promosi pun dilarang. Notaris dituntut keahlian dan keterampilannya dalam pelaksanaan tugas jabatannya, namun kepribadian yang baik berdasarkan sikap mandiri dan tidak memihak harus diutamakan. Sikap bebas atau mandiri serta jujur, berani berbuat sesuai hati nurani sangatlah penting supaya Notaris tidak memihak pada salah satu pihak yang menguntungkannya secara finansial atau yang membayar Notaris tersebut. Persaingan antar Notaris ataupun wilayah kerja yang mungkin saja sepi bisa saja memicu terjadinya pelanggaran Notaris, sehingga Notaris ingin memperluas jaringan dengan membuka 2 (dua) kantor, bahkan masih ditambah dengan pelanggaran lain yakni tidak membacakan akta. Kasus (seorang Notaris memiliki dua kantor) yang telah diberikan teguran tertulis hingga teguran kedua, sebagai berikut. Memang benar pembinaan dan pengawasan Notaris perlu dilakukan pemeriksaan protokol Notaris oleh Majelis Pengawas Daerah Notaris setempat; ternyata pada protokol Notaris SLR ditemukan adanya pelanggaran terhadap ketentuan Pasal 16 ayat (1) huruf d jo. Pasal 19 ayat (1), UndangUndang No. 30 Tahun 2004 tentang Jabatan Notaris, sehingga bersangkutan diberikan pembinaan dalam bentuk sanksi. Dengan berdasarkan pemeriksaan ataupun pengecekan alamat kantor (Surat dari Ketua Majelis Pengawas Daerah Notaris Kota Tangerang tanggal 25 Juni 2009 Nomor 195/K/ MPD/ VI/ 2009, 
Perihal Berita Acara Pengecekan Rumah/ Kantor, MPW telah memberikan sanksi berupa teguran tertulis (sampai kedua) kepada Notaris SLR. Sesuai dengan Pasal 85 huruf b Undang-Undang No. 30 Tahun 2004 tentang Jabatan Notaris.

\section{e. Permasalahan Plang Nama dan Pindah Alamat Tidak Melapor}

Contoh yang diberikan masih perihal Kantor Jalan Kisamaun, Kota Tangerang yang Terpampang Papan Nama SLR, yang sudah pindah ke Kabupaten Tangerang. MPW telah memberikan sanksi berupa teguran tertulis (sampai kedua) kepadanya. Sesuai dengan Pasal 85 huruf $b$ UUJN tentang Jabatan Notaris. Sebagai Terlapor Notaris tersebut telah mendapatkan sanksi teguran Tertulis dari Majelis Pengawas Wilayah Notaris Provinsi Banten tanggal 23 Desember 20008 Nomor W29/Not 41/2008/ MPW Provinsi Banten tentang Penjatuhan Sanksi Terhadap Notaris; namun ketika terjadi pemekaran Kabupaten Tangerang dangan Kota Tangerang pada tahun 2000 Terlapor telah memilih Kabupaten Tangerang sebagai tempat kedudukannya, oleh karena itu telah pindah kantor dari alamat yang lama Jalan Kisamaun Kota Tangerang ke alamat yang baru jalan Raya Serpong Pondok Jagung, Serpong, Kabupatan Tangerang; namun tanpa melapor dan bahkan masih memasang plang nama Notaris. Dalam hal ini Terlapor mengakui menyimpan dokumen-dokumen sampai dengan tahun 2008 di Jalan Kisamaun Kota Tangerang, juga menempatkan karyawannya untuk menerima dokumen dan memberikan keterangan-keterangan yang berkaitan dengan kepentingan Notaris; sehingga karena teguran tertulis pertama tidak dihiraukan maka cukup alasan bagi Terlapor untuk diberikan sanksi berupa Teguran Tertulis Kedua.

Seharusnya Notaris yang beriktikad baik, akan melaporkan kepindahannya, dan tidak memasang plang nama yang mengelabui masyarakat, bahkan jelas dapat dinilai membuka kantor lebih dari ketentuan yang berlaku. Tindakan
Notaris ini sangat tidak terpuji dan melanggar kode etik, perlu diberikan sanksi yang tegas agar tidak menjadi preseden bagi Notaris lain. Jika dilakukan pembiaran, maka dimungkinkan akan banyak plang nama Notaris diberbagai tempat sebagai 'calo sertifikat' karena sebenarnya kantor yang terpampang plang nama tersebut hanya kosong, hanya sedikit berkas untuk mengelabui seakan-akan benar merupakan kantor, dan hanya ditunggui oleh satu karyawan saja.

Persaingan antar rekan Notaris yang tidak sehat semakin menjurus pada persaingan usaha tidak sehat antar rekan Notaris. Mereka pro aktif turun ke pasar mendatangi klien, menawarkan jasa, melakukan negosiasi honor dan melakukan perikatan layaknya pebisnis pada umumnya. ${ }^{10}$ Penulis sangat sependapat dengan P. Nicolai ${ }^{11}$ pengawasan merupakan langkah preventif untuk memaksakan kepatuhan. Penegakan hukum tidak boleh hanya dilakukan setengah-setengah, akan tetapi harus berkesinambungan, baik preventif dan represif.

\section{f. Notaris Membuat Salinan Akta Tidak Sesuai dengan Minuta}

Pada kasus Notaris RW, Notaris membuat salinan akta tidak sesuai dengan minuta akta. Pasal 16 dan 17 UUJN menentukan kewajiban dan larangan Notaris yaitu di antaranya bekerja secara seksama, mandiri, tidak berpihak, dan menjaga kepentingan pihak yang melakukan perbuatan hukum. Ketika seorang Notaris membuat salinan akta, Notaris harus mencocokkan dengan minuta aslinya, sesuai dengan kompetensinya, agar akta tidak kehilangan otentitasnya. Apabila dalam prakteknya, Notaris tidak membuat salinan akta tersebut sesuai dengan aslinya, maka Notaris tersebut telah melanggar kewenangan dan telah menyebabkan Minuta yang dibuatnya mengandung keterangan palsu. Selain dalam pembuatan salinan, dalam hal pembuatan Minuta pun Notaris harus berhati-hati jangan sampai mengandung keterangan palsu, jika tidak maka Notaris harus bertanggung

Pengurus Pusat INI, 2010, Jati Diri Notaris Indonesia: Dulu, Sekarang dan Masa Akan Datang, Gramedia Pustaka, Jakarta, hlm. 94. Ridwan H.R., 2002, Hukum Administrasi Negara, Rajawali Press, Jakarta, hlm. 311. 
jawab secara hukum. Bentuk tanggungjawab hukum Notaris adalah tanggung jawab terhadap hukum perdata, hukum pidana, UUJN, dan Kode Etik Notaris. Selain itu, seorang Notaris selaku pejabat umum, juga harus bertanggungjawab atas kebenaran materiil atas Minuta yang dibuatnya, di mana seorang Notaris harus menjamin bahwa minuta yang dibuatnya merupakan suatu Minuta yang otentik.

Sependapat dengan Wahyudi Sulistia Nugroho $^{12}$ yang menjelaskan bahwa dalam pembuatan akta yang dilakukan Notaris, setiap kata yang dibuat dalam akta harus terjamin otentisitasnya. Oleh karena itu, dalam proses pembuatan dan pemenuhan persyaratan pembuatan akta diperlukan tingkat kecermatan yang memadai.

Pada kasus RW sebagai Terlapor dan Pelapor adalah MPD (Majelis Pengawas Daerah) Kabupaten Tangerang/Kota Tangerang Selatan, Terlapor dilaporkan oleh Pelapor dengan Surat Majelis Pengawas Daerah Notaris Kabupaten Tangerang Kota Tangerang Selatan tanggal 15 Desember 2009, Nomor 50/MPD/Kab.Tgr-Kota Tangsel/XII/2009 Perihal Laporan Hasil Pemeriksaan Atas Laporan Masyarakat terhadap RW Notaris Kabupaten Tangerang-Kota Tangsel. Majelis Pemeriksa Wilayah Notaris Provinsi Banten dalam melakukan pemeriksaan terhadap Terlapor dan berkas laporan dari kuasa hukum Terlapor menemukan faktafakta bahwa Terlapor telah membuat akta kuasa menjual di mana para pihak baik pemberi kuasa maupun penerima kuasa tidak menandatangani akta tersebuat di hadapan Terlapor.

Terlapor dinilai tidak bertindak jujur, saksama, mandiri, berpihak dan menjaga kepentingan pihak yang terkait dalam pembuatan hukum. Pelanggaran lainnya adalah Terlapor membuat salinan akta tidak sesuai dengan minuta akta, Terlapor tidak membacakan akta di hadapan para penghadap dengan dihadiri oleh paling sedikit 2 (dua) orang saksi dan ditandatangani pada saat itu juga oleh para penghadap. Jadi menurut penulis, Notaris tersebut telah melanggar Pasal 16 ayat (1) huruf a Undang-Undang Nomor 30 Tahun 2004 tentang Jabatan Notaris yaitu tidak bertindak jujur, saksama, mandiri, berpihak dan menjaga kepentingan pihak yang terkait dalam pembuatan hukum. Selain itu telah melanggar Pasal 16 ayat (1) huruf c Undang-Undang Nomor 30 Tahun 2004 tentang Jabatan Notaris yaitu membuat salinan akta tidak sesuai dengan minuta akta. Selain itu, Notaris tersebut telah melanggar Pasal 16 ayat (1) huruf i Undang-Undang Nomor 30 Tahun 2004 tentang Jabatan Notaris yaitu Terlapor tidak membacakan akta di hadapan para penghadap dengan dihadiri oleh paling sedikit 2 (dua) orang saksi dan ditandatangani pada saat itu juga oleh para penghadap. Notaris tersebut melanggar Pasal 39 ayat (2), Pasal 40 ayat (1), Pasal 44 ayat (1), Pasal 54 Undang-Undang Nomor 30 Tahun 2004 tentang Jabatan Notaris, pelanggaran sebagaimana tersebut pada butir 3, 4, dan 5 dapat dikenai saksi dengan ketentuan sesuai dengan Pasal 85 Undang- undang Nomor 30 Tahun 2004 tentang Jabatan Notaris, pasal 84 Undang-Undang Nomor 30 Tahun 2004 tentang Jabatan Notaris. Sudah sepatutnya MPW berdasarkan Pasal 73 ayat (1) huruf e UndangUndang Nomor 30 Tahun 2004 tentang Jabatan Notaris memberikan sanksi berupa teguran lisan atau teguran tertulis. Selain itu berdasarkan Pasal 73 ayat (1) huruf $\mathrm{f}$ Majelis Pengawas Wilayah berdasar hasil pemeriksaan, berwenang mengusulkan pemberian sanksi terhadap Notaris terhadap Majelis Pengawas Pusat berupa pemberhentian sementara 3 (tiga) bulan sampai dengan 6 (enam) bulan sampai dengan pemberhentian tidak hormat.

Dalam hal pelanggaran Notaris, alangkah efektifnya jika MPD bisa diberdayakan agar secara langsung bisa memutuskan/memberi sanksi kepada Notaris pelanggar. Penulis sependapat Firdhonal ${ }^{13}$ yang menyatakan betapa pentingnya bila MPD memiliki kewenangan dalam menjatuhkan sanksi 
terhadap Notaris yang melanggar kode etik atau menyalahgunakan jabatan. Sejauh ini MPD hanya berwenang memberikan rekomendasi atas berita acara pemeriksaan, dan selanjutnya yang berhak memberikan sanksi adalah Majelis Pengawas
Wilayah dan Majelis Pengawas Pusat berupa teguran baik secara lesan maupun tertulis. Berikut disajikan rincian pelanggaran berdasarkan tahun dan daerah di Provinsi Banten.

Tabel 2.

Rincian Pelanggaran berdasarkan Tahun dan Daerah

\begin{tabular}{|c|c|c|c|c|c|c|c|c|}
\hline No. & Daerah & 2008 & 2009 & 2010 & 2011 & 2012 & 2013 & Jumlah \\
\hline 1. & Kab Serang dan Kota Cilegon & - & - & - & - & - & - & 0 \\
\hline 2. & Kota Serang & - & - & - & - & - & - & 0 \\
\hline 3. & Kab Pandeglang dan Lebak & - & - & - & - & - & - & 0 \\
\hline 4. & Kab Tangerang & 1 & 1 & 5 & 4 & - & 3 & 14 \\
\hline 5. & Kota Tangerang Selatan & - & - & 2 & 6 & - & - & 8 \\
\hline 6. & Kota Tangerang & 2 & 5 & - & - & - & 2 & 9 \\
\hline \multicolumn{2}{|c|}{ Jumlah } & 3 & 6 & 7 & 10 & 0 & 5 & 31 \\
\hline
\end{tabular}

Sumber: Hasil Penelitian di Sekretariat MPW Provinsi Banten Mei-Oktober 2013.

Dengan jumlah Notaris sekitar 1200 di Provinsi Banten, selama tahun 2008 sampai 2013 terdapat kasus pelanggaran sejumlah 31 kasus. Berdasarkan hasil penelitian diketahui bahwa kebanyakan terhadap pelanggaran tersebut telah diberikan teguran tertulis, dan hanya terdapat 1 (satu) kasus dengan usulan pemberhentian sementara, dikarenakan bentuk pelanggarannya tergolong cukup berat. Permasalahan Notaris tersebut dinilai cukup berat, karena selain telah membuat akta kuasa menjual di mana para pihak baik pemberi kuasa maupun penerima kuasa tidak menandatangani akta tersebut di hadapan Notaris terlapor, tidak bertindak jujur, saksama, mandiri, berpihak dan menjaga kepentingan pihak yang terkait dalam pembuatan hukum, yang bersangkutan juga membuat salinan akta tidak sesuai dengan minuta akta, serta tidak membacakan akta di hadapan para penghadap dengan dihadiri oleh paling sedikit 2 (dua) orang saksi dan ditandatangani pada saat itu juga oleh para penghadap.

Berikut disajikan penerapan sanksi oleh MPW Provinsi Banten terhadap pelanggaran Notaris yang terjadi antara tahun 2008 sampai dengan 2013.

Tabel 3.

Penerapan Sanksi oleh MPW Provinsi Banten terhadap Pelanggaran Notaris

\begin{tabular}{llccccccc}
\hline No & Putusan MPW & $\mathbf{2 0 0 8}$ & $\mathbf{2 0 0 9}$ & $\mathbf{2 0 1 0}$ & $\mathbf{2 0 1 1}$ & $\mathbf{2 0 1 2}$ & $\mathbf{2 0 1 3}$ & Jumlah \\
\hline 1 & Gugur & - & - & - & - & - & 2 & 2 \\
2 & Teguran Lisan & - & - & - & 5 & - & 1 & 6 \\
3 & Teguran tertulis & 3 & 5 & 4 & 2 & - & - & 14 \\
4 & Putusan Bebas & - & 1 & 2 & 3 & - & 2 & 8 \\
5 & Usulan Pemberhentian sementara & - & - & 1 & - & - & - & 1 \\
\hline Jumlah & 3 & 6 & 7 & 10 & & 5 & 31 \\
\hline
\end{tabular}

Sumber: Hasil Penelitian di Sekretariat MPW Provinsi Banten Mei - Oktober 2013.

Berdasarkan hasil penelitian bahwa faktor yang menyebabkan pelanggaran Notaris di Banten disebabkan oleh SDM (sumber daya manusia) itu sendiri dan pengawasan dan pembinaan terhadap Notaris.

Mengingat tanggungjawab dan kepercayaan yang besar dan berat di pundak Notaris tersebut, maka Notaris perlu dibina dan diawasi, yang semuanya bertujuan untuk mengangkat keluhuran martabat jabatan Notaris. Notaris dituntut untuk patuh terhadap peraturan perundangan dan tidak melakukan kesalahan atau pun perbuatan tercela di 
masyarakat. Kode Etik dijadikan panduan ataupun tolok ukur bagi perilaku tersebut. Dengan mengikuti pendapat Habieb Adjie ${ }^{14}$ bahwa Notaris sebagai jabatan kepercayaan wajib untuk menyimpan rahasia mengenai akta yang dibuatnya dan keterangan/pernyataan para pihak yang diperoleh dalam pembuatan akta, kecuali undang-undang memerintahkannya untuk membuka rahasia dan memberikan keterangan/pernyataan tersebut kepada pihak yang memintanya. Dalam hal ini Notaris berperan penting dalam pengarsipan dokumen penting, misalnya transaksi para pihak. Jadi seharusnya Notaris selalu menjaga kewibawaannya, baik dalam nejalankan jabatannya maupun ketika berperilaku dalam masyarakat.

Notaris sebagai profesional yang sekaligus pejabat umum yang melayani kepentingan masyarakat, seharusnya memegang teguh amanah yang telah dipercayakan oleh para pihak kepadanya. Merujuk dan sependapat dengan Habieb Adjie ${ }^{15}$ pelaksanaan tugas Notaris sebagai jabatan kepercayaan dimulai ketika calon Notaris disumpah atau mengucapkan janji berdasarkan agama masing-masing sebagai Notaris. Sumpah atau janji sebagai Notaris mengandung makna yang sangat dalam yang harus dijalankan dan mengikat selama menjalankan tugas jabatan sebagai Notaris. Sumpah atau janji tersebut mengandung dua hal yang harus dipahami yaitu: Notaris wajib bertanggungjawab kepada Tuhan, karena sumpah atau janji yang diucapkan berdasarkan agama masing-masing artinya segala sesuatu yang dilakukan Notaris dalam menjalankan tugas jabatannya akan diminta pertanggungjawabannya dalam bentuk yang dikehendaki Tuhan dan Notaris wajib bertanggungjawab kepada Negara dan masyarakat, artinya Negara telah memberi kepercayaan untuk menjalankan sebagai tugas negara dalam bidang hukum perdata, yaitu dalam pembuatan alat bukti berupa akta yang mempunyai kekuatan pembuktian sempurna dan kepada masyarakat yang telah percaya bahwa Notaris mampu memformulasikan kehendaknya ke dalam bentuk akta Notaris, dan percaya bahwa Notaris mampu menyimpan (merahasiakan) segala keterangan atau ucapan yang diberikan di hadapan Notaris.

Majelis Pengawas Wilayah Provinsi Banten telah berusaha untuk menginventarisasi penyimpangan tugas profesi Notaris, dari bentuk pelanggaran dengan membuka cabang yang mungkin untuk produksi akta, maupun kasus yang melanggar lainnya yang lebih kompleks seperti kasus Notaris RW. Menurut penulis, jika memang Kode Etik dilaksanakan untuk menegakkan UUJN dan menjaga keluhuran martabat jabatan Notaris, maka seharusnya penerapan sanksi Kode Etik ini lebih dipertegas, jangan hanya dikeluarkan dari keanggotaan INI. Karena bisa saja secara rasional, Notaris akan tetap berpraktek sebagaimana biasa tanpa harus menjadi anggota INI. Selain itu perlu diefektifkan peran INI dan Dewan Kehormatan, demi kepastian hukum agar penerapan sanksi menimbulkan efek jera dan konstruktif dalam organisasi Notaris. INI pun diharapkan tidak berlarut-larut dalam polemik organisasi, INI seharusnya menjadi ajang pemersatu para Notaris, bukan pemecah belah para Notaris, untuk itulah perlu dibangun kembali landasan yang kokoh bagi INI agar berfungsi seperti tujuan awalnya, dan mengutamakan keluhuran martabat jabatan Notaris, mengutamakan kepentingan organisasi secara keseluruhan sebagai pemersatu dan mengesampingkan kepentingan golongan/individu.

Pembinaan dan pengawasan Notaris akan dapat berhasil baik jika pihak yang melakukan pembinaan dan pengawasan itu pun menguasai dan memahami bidang kerja Notaris dan ketentuan hukumnya. INI pun harus terdiri atas anggota yang menjunjung tinggi profesionalisme dan keahlian berdasarkan kepakaran/senioritas atau rekam jejak yang baik dalam bidang kenotariatan. UUJN sebenarnya telah mewadahi hal ini dalam Pasal 67 
bahwa pengawasan Notaris dilakukan oleh Menteri. Menteri membentuk Majelis Pengawas dalam 3 (tiga) tingkatan yakni Majelis Pengawas Daerah (MPD) untuk Kabupaten/Kota, Majleis Pengawas Wilayah (MPW) untuk tingkat Provinsi dan Majelis Pengawas Pusat (MPP) untuk tingkat pusat. Majelis Pengawas terdiri atas 9 (sembilan) orang anggota yakni: 3 (tiga) orang dari unsur pemerintah, 3 (tiga) orang Notaris dan 3 (tiga) orang akademisi. Seyogyanya menurut pendapat penulis, baik dari pemerintah maupun akademisi mereka adalah orangorang yang memahami atau belajar kenotariatan dengan baik. Demikian pula bagi Notaris, meskipun nantinya bertugas mengawasi Notaris sejawat, hendaknya tidak memihak dan mengesampingkan subyektivitas. Majelis Pengawas secara normatif harus melaksanakan fungsinya secara ideal (das sollen), sehingga pertimbangan subyektif harus diabaikan, supaya tidak berpengaruh terhadap pengawasan tersebut karena menyangkut ikatan emosional teman/rekan seprofesi dan se-organisasi. Pembinaan notaris memang telah dilakukan oleh
MPW melalui kegiatan ilmiah seminar, pelatihan dan pertemuan lainnya untuk sosialisasi dan peningkatan keilmuan. Pengawasan terhadap Notaris dilakukan terhadap pekerjaan Notaris, meliputi pengawasan atas diri perilaku Notaris serta pengawasan administratif. Pekerjaan Notaris diawasi dengan cara memeriksa akta-akta Notaris serta Repertorium dan Klapper untuk diteliti apakah melanggar UUJN atau tidak.

Selain itu tuntutan moral dan kecerdasan serta kehati-hatian (cermat) harus selalu diperhatikan oleh Notaris, sehingga akta otentik yang dibuatnya benarbenar dapat menjamin kepastian hukum. Mengikuti pendapat Suhrawadi bahwa dibutuhkan kepastian hukum terhadap produk Notaris oleh karena itu pelayanan yang diberikan oleh Notaris harus benar-benar memiliki nilai dan bobot yang dapat diandalkan. ${ }^{16}$ Jadi, Notaris dituntut keahliannya dan kecermatannya serta dibekali moral yang kuat agar berperilaku menjaga harkat jabatannya. Untuk itu perlu diimbangi dengan pengawasan oleh instansi yang telah ditunjuk oleh UUJN.

Tabel 4.

Faktor Pemicu Pelanggaran dan Solusinya

\begin{tabular}{|c|c|c|}
\hline No. & Faktor Pemicu Pelanggaran & Solusinya \\
\hline 1. & Regulasi bidang kenotariatan & $\begin{array}{l}\text { Perlunya reformasi regulasi kenotariatan agar UUJN } \\
\text { dan Kode Etik lebih efektif menuju kepastian hukum. }\end{array}$ \\
\hline 2. & Peran organisasi & Perlunya revitalisasi organisasi. \\
\hline 3. & $\begin{array}{l}\text { Masalah SDM dari pendidikan, rekruitmen } \\
\text { dan praktek, serta antisipasi masalah } \\
\text { tuntutan persaingan, kesejahteraan, moral } \\
\text { integritas }\end{array}$ & $\begin{array}{l}\text { Perlunya mengatasi masalah SDM dari pendidikan, } \\
\text { rekruitmen dan praktek, serta antisipasi masalah } \\
\text { tuntutan persaingan, kesejahteraan, moral integritas. }\end{array}$ \\
\hline 4. & Pengawasan & $\begin{array}{l}\text { Perlunya pengawasan yang berkesinambungan dengan } \\
\text { peran aktif lembaga yang relevan, didukung lembaga } \\
\text { yang independen. }\end{array}$ \\
\hline 5. & $\begin{array}{l}\text { Pembinaan dan } \quad \text { peningkatan } \\
\text { profesionalisme }\end{array}$ & $\begin{array}{l}\text { Perlunya pembinaan dan peningkatan skill serta } \\
\text { profesionalisme melalui sosialisasi, peningkatan kinerja, } \\
\text { ketahanan (retensi), studi lanjut/kegiatan ilmiah. }\end{array}$ \\
\hline
\end{tabular}

Sumber: Data dianalisis oleh Penulis, Tahun 2014.

Dalam rangka penegakan hukum, selain sehingga dapat dilanjutkan pemeriksaan oleh regulasi yang lebih menjamin kepastian hukum, Majelis Pengawas Daerah Notaris Daerah meskipun perlu pembinaan dan pengawasan Notaris dengan wewenang pemberian sanksi selama ini masih melakukan pemeriksaan atas laporan masyarakat berada pada Majelis Pengawas Pusat Notaris.

16 Suhrawadi K. Lubis, 1994, Etika Profesi Hukum, Sinar Grafika, Jakarta, hlm. 33. 
2. Penegakan Hukum Preventif terhadap Pelanggaran Hukum oleh Notaris di Wilayah Provinsi Banten

Penegakan hukum bisa dilakukan secara preventif maupun secara represif. Secara preventif dapat dilakukan dengan regulasi guna menjamin kepastian hukum dan pengawasan, sedangkan secara represif yakni dengan memberikan hukuman/ sanksi. Menurut analisis penulis, berdasarkan hasil penelitian, bahwa upaya pencegahan pelanggaran di Provinsi Banten dapat dilakukan dengan baik melalui:

\section{a. Pembinaan oleh Institusi Terkait}

MerujukpadaLawrenceM. Friedman ${ }^{17}$ bahwa dalam sebuah sistem hukum terdapat tiga komponen penting yang saling mempengaruhi, yaitu: struktur hukum (legal structure), substansi hukum (legal substance), dan budaya hukum (legal culture). Struktur menyangkut aparat penegak hukum, kemudian substansi meliputi perangkat perundangundangan, dan budaya hukum merupakan hukum yang hidup yang dianut dalam suatu masyarakat. Struktur dari sistem hukum terdiri dari lembaga hukum yang ada dimaksudkan untuk menjalankan perangkat hukum yang ada, sedangkan substansi hukum adalah aturan, norma dan pola perilaku nyata manusia yang berada dalam sistem itu, menyangkut peraturan perundang-undangan yang berlaku yang memiliki kekuatan yang mengikat dan menjadi pedoman bagi aparat penegak hukum sehingga menghasilkan suatu produk, mencakup keputusan yang mereka keluarkan, aturan baru yang mereka susun. Budaya hukum sering tercermin dalam kesadaran hukum itu sebagai suatu keseluruhan yang mencakup pengetahuan tentang hukum, berlakunya fungsi hukum, dan kepatuhan kepada hukum. Untuk mendukung teori Friedmann tersebut, perlu dilakukan penegakan hukum yang konsisten. Merujuk pada pendapat Soerjono Soekanto ${ }^{18}$ bahwa faktor-faktor penegakan hukum terdiri atas: (1) faktor hukumnya sendiri, (2) faktor penegak hukumnya, (3) faktor sarana dan fasilitas penegakan hukum, (4) faktor masyarakat dan (5) faktor kebudayaan; kelima faktor tersebut saling berkaitan dengan erat, oleh karenanya merupakan esensi dari penegakan hukum, juga merupakan tolok ukur efektivitas penegakan hukum.

MPW Provinsi Banten telah menjelaskan penegakan hukum yang bersifat preventif melalui upaya pencegahan pelanggaran hukum oleh Notaris yang telah dilakukan dan akan terus dilakukan adalah dengan melakukan pembinaan dan pengawasan terhadap Notaris, yaitu dengan cara: (1) pemeriksaan protokol Notaris tahunan/ berkala; dan (2) sosialisasi UU Jabatan Notaris No. 30 Tahun 2004 dan aturan pelaksanaannya.

Selama ini telah dilakukan pembinaan oleh instansi terkait Departemen Hukum dan HAM, Pengurus INI, Dewan Kehormatan dan Majelis Pengawas melalui kegiatan rutin, kegiatan ilmiah, pengayaan materi keilmuan yang relevan dengan bidang kerja Notaris dan sosialisasi peraturan perundangan.

\section{b. Koordinasi dan Kerjasama antara Notaris dan INI}

Perlu dibenahi kerjasama yang telah dilakukan selama ini agar koordinasi dan kerjasama yang baik makin ditingkatkan berdasarkan silahturahim yang saling membutuhkan antara Notaris dan INI sebagai pemersatu. Antara Notaris, Pengurus INI, Departemen Hukum dan HAM, Dewan Kehormatan dan Majelis Pengawas melalui kegiatan ilmiah dan silahturahmi harus bisa memupuk rasa solidaritas profesi yang lebih baik, menjunjung perilaku yang sesuai dengan Kode Etik dan bekerja sama secara mutualisme dalam pengayaan materi keilmuan yang relevan dengan bidang kerja Notaris.

Koordinasi dan kerjasama tidak hanya sebatas urusan menyelesaikan pembuatan akta, lebih dari itu berkaitan dengan pengawasan terhadap Notaris mengingat permasalahannya berintikan SDM dan pengawasan, maka perlu dipersiapkan alur sejak 
rekruitmen Notaris (dari pendidikan dan ujian kompetensi, maupun izin praktek) hingga menjadi Notaris dan berpraktek sehari-hari dengan regulasi (bisa dengan peraturan organik di bawah UUJN) yang tepat dan tegas. Maksudnya UUJN, Kode Etik dan pengawasannya harus berjalan sinergi dan saling mendukung dengan INI. Dalam rangka peningkatan mutu SDM, Notaris seharusnya lebih berusaha untuk terus belajar, agar senantiasa dapat mengikuti perkembangan global, dimulai pada saat seleksi pendidkan, rekruitmen dan saat berpraktek menjadi Notaris. Ini dilakukan dengan pelbagai cara ilmiah yang relevan dalam pembentukan profesi yang menjunjung tinggi profesionalitasnya sesuai Kode Etik Notaris, misalnya peningkatan mutu dan kinerja, pendidikan dan seleksi yang lebih baik dengan syarat izin praktek dan magang yang lebih rigid.

\section{b. Pengawasan yang Kontinu}

Dalam upaya menjaga Notaris agar menegakkan tugas jabatan mulia tersebut, maka dilakukan pengawasan. Pengawasan seharusnya lebih difokuskan dengan tujuan upaya preventif pelanggaran dan sebagai rambu efektivitas penegakan hukum yang lebih menjamin kepastian hukum. Pengawasan ini tujuannya adalah pencegahan terhadap terjadinya pelanggaran yang merugikan masyarakat. Seharusnya menurut penulis tujuan pengawasan bukan hanya untuk pencegahan akan timbulnya pelanggaran, akan tetapi juga untuk mendukung penerapan UUJN menuju kepastian hukum, secara moral juga mendukung efektifitas Kode Etik, dan secara represif juga untuk memberi rambu-rambu akan adanya hukuman/sanksi, bahwa perilaku, etik, dan pelaksanaan jabatan Notaris selalu dinilai dan diawasi oleh masyarakat melalui Majelis Pengawas dan Dewan Kehormatan.

Merujuk Pasal 67-76 UUJN, Pengawasan atas Notaris dilakukan oleh Menteri melalui Majelis Pengawas, baik tingkat MPD, MPW maupun MPP. Pengawasan tersebut meliputi perilaku Notaris dan pelaksanaan jabatan Notaris. Demikian jika merujuk Kode Etik Notaris utamanya tentang Tata Cara Penegakan Kode Etik, maka dalam Pasal 7 tentang Pengawasan, pengawasan atas pelaksanaan Kode Etik dilakukan oleh Pengurus INI dan Dewan Kehormatan. Dewan Kehormatan (Pasal 8 Kode Etik) merupakan alat perlengkapan perkumpulan yang berwenang melakukan pemeriksaan atas pelanggaran Kode Etik dan menjatuhkan sanksi kepada pelanggarnya sesuai dengan kewenangan masing-masing.

\section{d. Perlunya Lembaga Pengawas yang Lebih Independen dan Profesional}

Guna mendukung kinerja Notaris agar lebih profesional dalam menjaga harkat martabatnya melaksanakan tugas jabatannya, tentu diperlukan peran lembaga yang lebih mandiri dan tidak berpihak, yang untuk menilai dan memeriksa serta mengawasi pelaksanaan tugas jabatan Notaris, mengingat pengawasan yang dilakukan terhadap Notaris, terkait UUJN dan Kode Etik, dilakukan oleh Majelis Pengawas (yang di dalamnya terdapat tiga Notaris sewilayah kerja/sejawat) dan Dewan Kehormatan serta Pengurus INI (yang notabene adalah Notaris di wilayah kerja yang sama pula). Lembaga independen ini haruslah profesional yang menguasai kenotariatan dengan baik, atau pun profesi yang telah menyelesaikan studi notariat, senior dalam bidang ilmu notariat, akan tetapi tidak berpraktek sebagai Notaris.

\section{Kesimpulan}

Berdasarkan uraian pembahasan di atas, dapat ditarik kesimpulan bahwa: Pertama, bentukbentuk pelanggaran hukum yang terjadi dalam pelaksanaan jabatan Notaris dan Profesi Notaris di Provinsi Banten antara lain: (1) tidak membacakan akta, (2) tidak tanda tangan di hadapan Notaris, (3) berada di wilayah kerja yang telah ditentukan, (4) membuka kantor lebih dari 1, (5) plang nama Notaris terpampang akan tetapi kosong, (6) pindah alamat kantor akan tetapi tidak melapor, dan (7) membuat salinan akta tidak sesuai dengan minuta.

Kedua, penegakan hukum dilakukan baik preventif maupun represif. Selain memberikan hukuman/sanksi sebagai bentuk penegakan represif, MPW Banten telah berupaya untuk lebih 
keras mencegah tindak pelanggaran hukum Notaris yang dilakukan dengan: (1) pembinaan oleh instansi terkait Departemen Hukum dan HAM, Pengurus INI, Dewan Kehormatan dan Majelis Pengawas; dan sosialisasi peraturan perundangan; (2) koordinasi dan kerjasama yang baik dalam peningkatan mutu dan kinerja antara Notaris dan INI sebagai pemersatu; (3) pengawasan yang kontinu baik dari rekruitmen hingga Notaris berpraktik (secara periodik terhadap protokol maupun produk Notaris); sekaligus pengawasan dengan tujuan upaya preventif dan sebagai rambu efektivitas penegakan hukum yang lebih menjamin kepastian hukum; dan (4) diperlukan lembaga independen yang lebih mandiri untuk menilai dan memeriksa serta mengawasi pelaksanaan tugas jabatan Notaris.

\section{DAFTAR PUSTAKA}

\section{A. Buku}

Adjie, Habieb, 2009, Meneropong Khasanah Notaris dan PPAT Indonesia, Citra Aditya Bakti, Bandung.

Adjie, Habieb, 2008, Sanksi Perdata dan Administrasi terhadap Notaris Sebagai Pejabat Publik, Refika Aditama, Bandung.

Adjie, Habieb, 2009, Sekilas Dunia Notaris dan PPAT Indonesia, Mandar Maju, Bandung.

Anshori, Abdul Ghofur, 2009, Lembaga Kenotariatan Indonesia Perspektif Hukum dan Etika, UII Press, Yogyakarta.

Friedman, Lawrence M., 1969, The Legal System: A Social Science Perspective, Russel Soge Foundation, New York.

H.R., Ridwan, 2002, Hukum Administrasi Negara, Rajawali Press, Jakarta.

Kie, Tan Thong, 2007, Studi Notariat-Serba Serbi Praktek Notaris, Ichtiar Baru, Van Hoeve, Jakarta.

Koesoemawati, Ira dan Yunirman Rijan, 2009, Ke Notaris Mengenal Profesi Notaris Memahami Praktek Kenotariatan Ragam Dokumen Penting yang Diurus Notaris dan Tips Tidak Tertipu Notaris, Raih Asa Sukses, Jakarta.

Lubis, Suhrawadi K., 1994, Etika Profesi Hukum, Sinar Grafika, Jakarta.

Notodisoerjo, R. Soegondo, 1993, Hukum Notariat Indonesia (Suatu Penjelasan), Raja Grafindo Persada, Jakarta.

Majelis Pengawas Wilayah Notaris Provinsi Banten, 2008, Pedoman dan Tata Cara Penyusunan Program Kerja Majelis Pengawas Daerah
Notaris sewilayah Banten, MPWN Prov. Banten, Banten.

Pengurus Pusat INI, 2010, Jati Diri Notaris Indonesia: Dulu, Sekarang dan Masa Akan Datang, Gramedia Pustaka, Jakarta.

Siswanto, Arie, 2002, Hukum Persaingan Usaha, Ghalia Indonesia, Jakarta.

Soekanto dan Muhammad, 2006, Potret Lembaga Pengadilan Indonesia, Raja Grafindo Persada, Jakarta.

Soekanto, Soerjono, 2011, Faktor-Faktor yang Mempengaruhi Penegakan Hukum, Raja Grafindo, Jakarta.

Sugiyono, 2005, Memahami Penelitian Kualitatif, Alvabeta, Bandung.

Tedjosaputra, Liliana, 1995, Etika Profesi Notaris dalam Penegakan Hukum Pidana, Bayu Grafika, Yogyakarta. , 2003, Etika Profesi dan Profesi Hukum, Aneka Ilmu, Semarang.

Tobing, GHS Lumban, 1983, Peraturan Jabatan Notaris, Erlangga, Jakarta.

\section{B. Jurnal/Majalah}

Firdhonal, "MPD Seharusnya Bisa Menjatuhkan Sanksi”, Majalah RENVOI, No. 8.116.X, Januari 2013.

Nugroho, Wahyudi Sulistia, "Pembatalan Akta Notaris oleh Hakim", Jurnal ADIL, Vol. 1, No. 3, Desember 2010.

\section{Sumber Internet}

Sofyan, Syafran, "Notaris Bukan Tukang, Jangan 
Takut Dipanggil Penyidik", http://www. medianotaris.com, diakses 1 Oktober 2012.

Suryandono, "Sudah Pindah Tapi Masih Pasang Papan Nama", http://www.medianotaris.com, diakses 1 Oktober 2012.

Wiryomartani, Winanto, "Sudah Pindah Tapi Masih Pasang Papan Nama", http://www. medianotaris.com, diakses 1 Oktober 2012. 